\title{
The management of postoperative COVID-19 pneumonia in a case with right pneumonectomy
}

\author{
Sağ pnömonektomi uygulanan bir olguda ameliyat sonrası COVID-19 pnömoni yönetimi

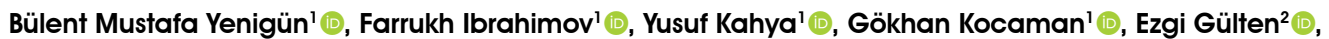 \\ Mehmet Serhat Birengel ${ }^{2}\left({ }^{-}\right.$, Cabir Yüksel' $^{1}$, Hakan Kutlay' ${ }^{(0)}$ \\ 'Department of Thoracic Surgery, Ankara University School of Medicine, Ankara, Turkey \\ 2Department of Infectious Diseases and Clinical Microbiology, Ankara University School of Medicine, Ankara, Turkey
}

\begin{abstract}
A 61-year-old male patient was hospitalized for the evaluation of a lung mass. The patient underwent right pneumonectomy. Although reverse-transcription polymerase chain reaction tests were negative for COVID-19, the diagnosis was supported by thoracic computed tomography. The patient responded to COVID-19 treatment, as evidenced by thoracic computed tomography. This case report highlights the importance of prompt diagnosis and treatment of COVID-19 in a patient who underwent pneumonectomy, which has high mortality and morbidity rates.
\end{abstract}

Keywords: Pneumonectomy, pneumonia, thoracic surgery.

Coronavirus disease 2019 (COVID-19) is caused by a novel coronavirus, namely severe acute respiratory syndrome coronavirus-2 (SARS-CoV-2). The first case of COVID-19 was reported in Wuhan, China, in late December. ${ }^{[1]}$ On March 2020, COVID-19 was declared as a pandemic by the World Health Organization (WHO). Patients with COVID-19 can be asymptomatic; however, the disease can progress to pneumonia, respiratory failure, and even death. Due to high mortality rates of COVID-19 and high occupancy rate in the intensive care units, many surgical associations have recommended ceasing all elective surgeries, until the transmission of COVID-19 has slowed. However, these recommendations are relatively complicated for thoracic surgeons, since
$\ddot{O} Z$

Atmış bir yaşında erkek hasta, akciğerde kitle değerlendirmesi için hastaneye yatırıldı. Hastaya sağ pnömonektomi uygulandı. Revers transkriptaz polimeraz zincir reaksiyon testleri COVID-19 için negatif olsa da tan1 toraks bilgisayarlı tomografi ile desteklendi. Toraks bilgisayarlı tomografi ile değerlendirildiği üzere, hastada COVID-19 tedavisine yanıt izlendi. Bu olgu sunumu, mortalite ve morbidite oranları yüksek olan pnömonektomi yapılan bir hastada hızlı COVID-19 tanı ve tedavisinin önemini göstermektedir.

Anahtar sözcükler: Pnömonektomi; pnömoni, göğüs cerrahisi.

most of their patients are oncological patients who should have surgery. ${ }^{[2]}$

In this article, we present a case of radiologically and clinically diagnosed with COVID-19 early after lung cancer surgery.

\section{CASE REPORT}

A 61-year-old male patient was hospitalized for the evaluation of a lung mass. Systemic examination was unremarkable and vital signs were stable. He had a 20 pack-year history of smoking. Evaluation of respiratory reserves were as follows: forced expiratory volume (FEV1): $2.56(67 \%)$, forced vital capacity (FVC): 2.64 (75\%), and diffusing capacity

Received: May 11, 2020 Accepted: August 04, 2020 Published online: April 26, 2021

Correspondence: Bülent Mustafa Yenigün, MD. Ankara Üniversitesi Tıp Fakültesi Göğüs Cerrahisi Anabilim Dalı, 06590 Çankaya, Ankara, Türkiye. Tel: +90 312 - 5083165 e-mail: drbulent18@hotmail.com 


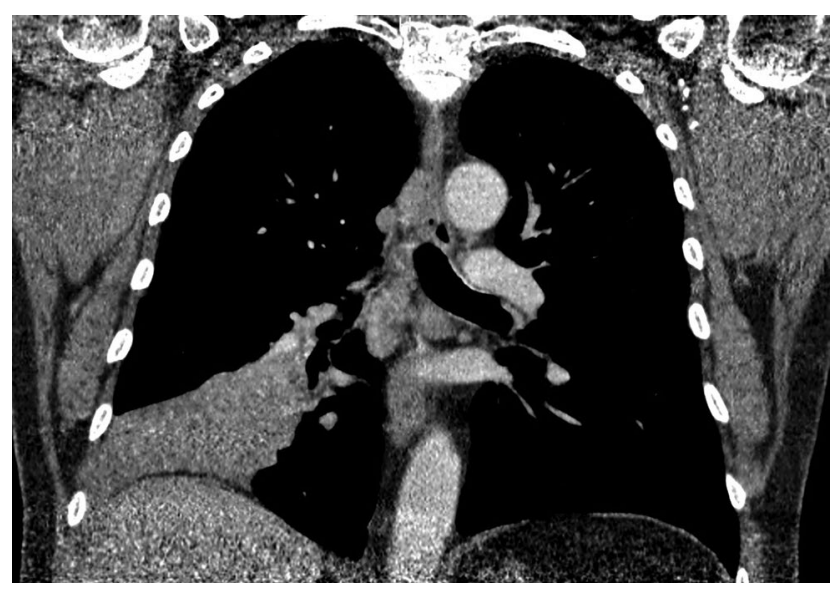

Figure 1. Mass appearance extending to hilar region of right hemithorax.

for carbon monoxide (DLCO): 92\%. Preoperative echocardiographic evaluation revealed no cardiac pathology and pulmonary artery pressure was $30 \mathrm{mmHg}$. A $70 \times 45-\mathrm{mm}$ sized mass located in the lower lobe of the right lung was observed on thoracic computed tomography (CT) (Figure 1). The major fissure was invaded by the mass. Positron emission tomography (PET) showed pathological 18F-fluorodeoxyglucose (FDG) uptake with a maximum standardized uptake value $\left(S U V_{\max }\right)$ of 17.8. The patient underwent bronchoscopy with endobronchial ultrasound (EBUS) for the evaluation of the mediastinal and hilar lymph nodes. Lymph node stations $2 \mathrm{R}, 7$ and $10 \mathrm{R}$ were sampled. The cytological diagnoses were found to be benign. An endobronchial lesion was observed inside the right lower lobe bronchus. A punch biopsy was taken from the lesion.

Histopathological examination was reported as a bronchial carcinoid tumor. The patient underwent right pneumonectomy and systematic mediastinal lymph node dissection through a right thoracotomy incision. The patient was discharged on postoperative Day 3 without any complication.
On postoperative Day 9, the patient was admitted due to dry cough and dyspnea. Vital signs were as follows: blood pressure: $130 / 90 \mathrm{mmHg}$, respiration: 20 breaths/min, pulse: $90 \mathrm{bpm}$, body temperature: $37^{\circ} \mathrm{C}$, and peripheral capillary oxygen saturation $\left(\mathrm{SpO}_{2}\right): 98 \%$ on ambient air. Breath sounds were not heard at the right hemithorax of the pneumonectomized patient. However, breath sounds were normal at the left hemithorax. Laboratory values were as follows: leukocyte: $10.9 \times 10^{9} / \mathrm{L}, \quad$ lymphocytes: $1.9 \times 10^{9} / \mathrm{L}$, D-dimer: 3,108 ng/dL, and C-reactive protein (CRP): $97 \mathrm{mg} / \mathrm{L}$ (Table 1).

A nasopharyngeal swab sample was taken from the patient twice within $48 \mathrm{~h}$. Also, pleural fluid samples were taken from the pneumonectomy cavity. Reverse-transcription polymerase chain reaction (RT-PCR) for SARS-CoV-2 was performed using all samples and all results were reported as negative. Thoracic CT revealed peripheral ground-glass opacity (GGO) with irregular contours located in left lung (Figures 2 and 3). The patient was isolated for 14 days. He was treated with oral hydroxychloroquine sulfate $200 \mathrm{mg}$ b.i.d. for five days, oral azithromycin $500 \mathrm{mg}$ daily for five days, oral oseltamivir $75 \mathrm{mg}$ b.i.d. for five days, and intravenous piperacillin/tazobactam $4.5 \mathrm{~g}$ t.i.d. for seven days. Prophylactic dose of enoxaparin 4,000 IU once daily was added to the treatment to prevent the embolic complications of COVID-19. The patient was given $02(2 \mathrm{~L} / \mathrm{min}) \mathrm{O}_{2}$ through the nasal cannula during the hospital stay.

Histopathological examination was reported as an atypical bronchial carcinoid tumor and benign mediastinal lymph nodes. The Ki-67 proliferation index of the tumor was reported as $23 \%$. Therefore, adjuvant chemotherapy was planned for the patient. Our patient was discharged after COVID-19 treatment and a 14-day isolation period. He is still under follow-up without any problems in our outpatient clinic.

Table 1. Postoperative laboratory test results

\begin{tabular}{lcccccc}
\hline Postoperative & $7^{\text {th }}$ day & $9^{\text {th }}$ day & $11^{\text {th }}$ day & $16^{\text {th }}$ day & $20^{\text {th }}$ day & Reference range \\
\hline Leukocytes $\left(\times 10^{9} / \mathrm{L}\right)$ & 11.45 & 10.9 & 11.61 & 8.53 & 9.2 & $4.5-11$ \\
Lymphocytes $\left(\times 10^{9} / \mathrm{L}\right)$ & 1.9 & 1.45 & 1.54 & 2.55 & 1.98 & $1.5-4$ \\
Neutrophiles $\left(\times 10^{9} / \mathrm{L}\right)$ & 7.68 & 7.89 & 8.59 & 4.64 & 5.93 & $1.8-7.7$ \\
D-dimer $(\mathrm{ng} / \mathrm{mL})$ & 732 & 3108 & 670 & 1073 & 117 & $0-243$ \\
C-reactive protein $(\mathrm{mg} / \mathrm{L})$ & 55.6 & 97 & 83.4 & 31.3 & 21 & $0-5$ \\
\hline
\end{tabular}




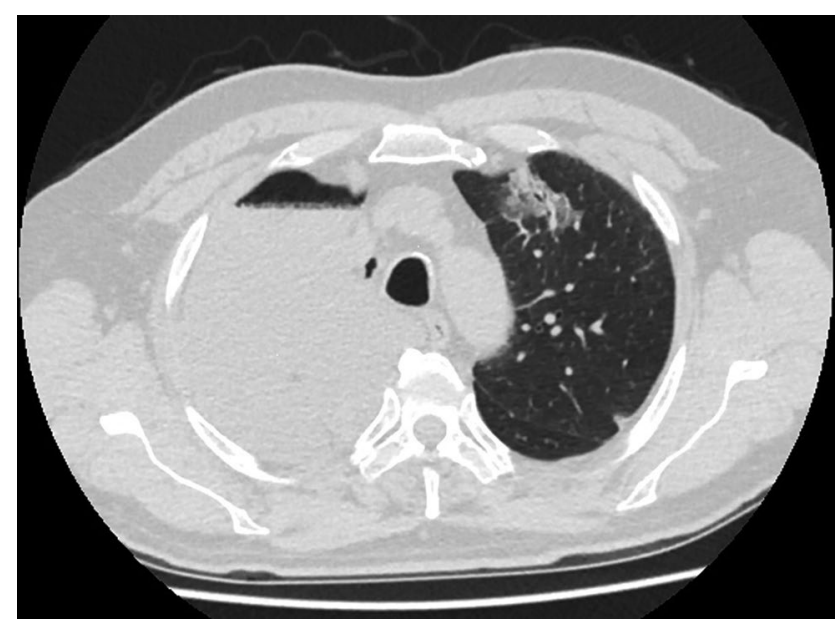

Figure 2. Peripherally located ground-glass opacity view of the upper lobe of left lung.

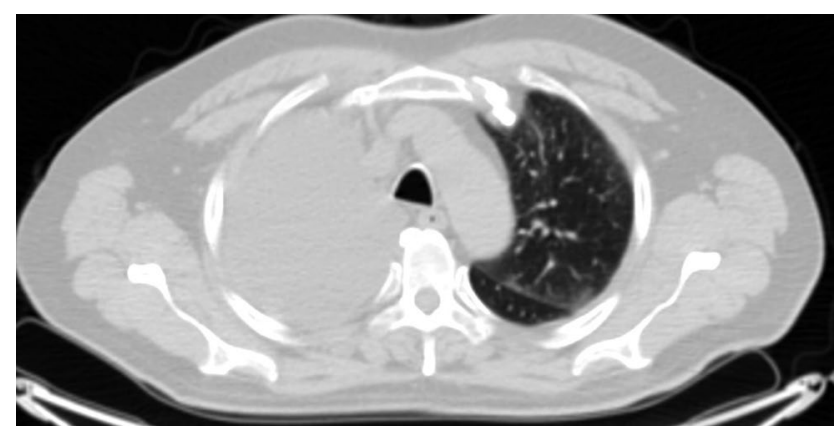

Figure 3. Thoracic computed tomography section showing that lesion disappeared completely after COVID-19 treatment.

\section{DISCUSSION}

The COVID-19 pandemic has forced hospitals to progressively reduce surgical volumes to both minimize disease transmission within the hospital and to preserve human and personal protective equipment and other resources needed to care for COVID-19 patients. However, it is very difficult to decide on the timing of oncological surgery during the pandemic. In this context, three options are available: (i) Surgery is not delayed; (ii) Surgery can be postponed; and (iii) The patient can be referred to an alternative therapy. These options should be discussed in the Multidisciplinary Tumor Councils. ${ }^{[2]}$ The first case of COVID-19 was confirmed in Turkey on March $11^{\text {th }}, 2020$. As our patient was hospitalized before this date, we did not postpone surgery.

Patients with COVID-19 have had a wide range of symptoms ranging from mild symptoms to severe illness. Common symptoms at the onset of illness are fever (98\%), cough (76\%), and myalgia or fatigue (44\%), while dyspnea can be also seen in $55 \%$ of patients. ${ }^{[3,4]}$ Dyspnea and cough are expected symptoms in the early postoperative period in pneumonectomized patients. The reasons can be listed as follows: decrease in respiratory capacity after resection, infection, bronchopleural fistula, and hemorrhage. However, as our hospital is a pandemic hospital, COVID-19 pneumonia was considered in the differential diagnosis of this patient.

A wide variety of thoracic CT findings in COVID-19 has been reported in the different studies. However, all studies indicate that the main thoracic CT feature of COVID-19 pneumonia is the presence of GGO (86\%), typically with a peripheral and subpleural distribution. The other thoracic CT findings are consolidations (29\%) and linear focal atelectatic changes (14\%). ${ }^{[5]}$ Peripherally located GGO and consolidation were also detected on thoracic CT in our patient. If COVID-19 pneumonia causes acute respiratory distress syndrome $(30 \%)$, bilateral diffuse consolidations are observed in thoracic $\mathrm{CT} .{ }^{[3-7]}$

The diagnosis of COVID-19 must be confirmed by SARS-CoV-2 RT-PCR testing. However, with limitations of sample collection and transportation and inadequate kit performance, the total positive rate of SARS-CoV-2 RT-PCR for throat swab samples was reported to be about 30 to $60 \%$ at the initial presentation. In the current emergency, the low sensitivity of SARS-CoV-2 RT-PCR implies that many COVID-19 patients can be unrecognized and cannot receive appropriate treatment in time. Such patients constitute a risk for infecting a larger population given the highly contagious nature of the virus. However, thoracic CT had a higher sensitivity for the diagnosis of COVID-19, compared to initial SARS-CoV-2 RT-PCR testing from swab samples. ${ }^{[6,7]}$

In a study by $\mathrm{Ai}$ et al., ${ }^{[8]}$ involving 1,014 patients in Wuhan, China who underwent both thoracic CT and SARS-CoV-2 RT-PCR testing, the authors reported $97 \%$ sensitivity of thoracic CT in suggesting COVID-19, based on positive SARS-CoV-2 RT-PCR results, and $75 \%$ in patients with negative SARS-CoV-2 RT-PCR results, but showing positive thoracic CT findings. They concluded that thoracic CT had a high sensitivity for the diagnosis of COVID-19 and could be considered as a primary tool for the current COVID-19 detection in epidemic areas. Another study by $\mathrm{Li}$ and $\mathrm{Xia}^{[9]}$ in 53 patients concluded that thoracic CT had a low rate of missed diagnosis of COVID-19 $(3.9 \%, 2 / 51)$ and might be useful as a standard method for the rapid diagnosis of COVID-19 to optimize the management of patients. In patients with negative SARS-CoV-2 RT-PCR results, if 
clinical and radiological findings are compatible with COVID-19, isolation and medical treatment should be started immediately. ${ }^{[8-10]}$ Although SARSCoV-2 RT-PCR results were negative in our patient, we immediately isolated our patient and started his treatment promptly.

In conclusion, no specific medication and vaccination is recommended to treat COVID-19 patients currently. However, governments and pharmaceutical companies are actively involved in the struggle of finding an effective drug to defeat the coronavirus as early as possible. Identifying infected individuals and advising them to self-isolate for the duration of the infection minimize the risk of transmission of the virus to the others, thereby, slowing the spread. In addition, patients undergoing pneumonectomy for lung cancer are thought to be at a high risk for the development of postoperative pulmonary complications and these complications are associated with high mortality rates. Pneumonia is considered as one of the most common and serious complications after pneumonectomy. If early and effective treatment is applied, pneumonia can be successfully treated in patients with pneumonectomy. Successful outcomes can be achieved with prompt diagnosis and treatment in patients with COVID-19 pneumonia after pneumonectomy.

\section{Declaration of conflicting interests}

The authors declared no conflicts of interest with respect to the authorship and/or publication of this article.

\section{Funding}

The authors received no financial support for the research and/or authorship of this article.

\section{REFERENCES}

1. Carbone M, Green JB, Bucci EM, Lednicky JA. Coronaviruses: Facts, Myths, and Hypotheses. J Thorac Oncol 2020;15:675-8.

2. Thoracic Surgery Outcomes Research Network, Inc, Antonoff M, Backhus L, Boffa DJ, Broderick SR, Brown LM, et al. COVID-19 Guidance for Triage of Operations for Thoracic Malignancies: A Consensus Statement From Thoracic Surgery Outcomes Research Network. Ann Thorac Surg 2020;110:692-6.

3. Huang C, Wang Y, Li X, Ren L, Zhao J, Hu Y, et al. Clinical features of patients infected with 2019 novel coronavirus in Wuhan, China. Lancet 2020;395:497-506.

4. Çınar HNU, İnce Ö, Çelik B, Saltabaş F, Özbek M. Clinical course of COVID-19 pneumonia in a patient undergoing pneumonectomy and pathology findings during the incubation period. Swiss Med Wkly 2020;150:w20302.

5. Zhu N, Zhang D, Wang W, Li X, Yang B, Song J, et al. A Novel Coronavirus from Patients with Pneumonia in China, 2019. N Engl J Med 2020;382:727-33.

6. Kanne JP. Chest CT Findings in 2019 Novel Coronavirus (2019-nCoV) Infections from Wuhan, China: Key Points for the Radiologist. Radiology 2020;295:16-7.

7. Chung M, Bernheim A, Mei X, Zhang N, Huang M, Zeng X, et al. CT Imaging Features of 2019 Novel Coronavirus (2019nCoV). Radiology 2020;295:202-7.

8. Ai T, Yang Z, Hou H, Zhan C, Chen C, Lv W, et al. Correlation of Chest CT and RT-PCR Testing for Coronavirus Disease 2019 (COVID-19) in China: A Report of 1014 Cases. Radiology 2020;296:E32-E40.

9. Li Y, Xia L. Coronavirus Disease 2019 (COVID-19): Role of Chest CT in Diagnosis and Management. AJR Am J Roentgenol 2020;214:1280-6.

10. Feng H, Liu Y, Lv M, Zhong J. A case report of COVID-19 with false negative RT-PCR test: necessity of chest CT. Jpn J Radiol 2020;38:409-10. 